NOTES AND COMMENTS

\title{
FIRST OCCURRENCE OF PARASITOID Spalangia endius (WALKER) (HYMENOPTERA: PTEROMALIDAE) IN PUPAE OF Zaprionus indianus GUPTA (DIPTERA: DROSOPHILIDAE) IN BRAZIL
}

\author{
MARCHIORI, C. H. ${ }^{1}$ and SILVA, C. G. ${ }^{2}$ \\ ${ }^{1}$ Instituto Luterano de Ensino Superior de Itumbiara-ILES-ULBRA, Avenida Beira Rio, 1001, C.P. 23-T, \\ CEP 75500-000, Itumbiara, Goiás, Brazil \\ ${ }^{2}$ Mestrado em Entomologia da Universidade Federal de Lavras-UFLA, C.P. 37, \\ CEP 37200-000, Lavras, Minas Gerais, Brazil \\ Correspondence to: Carlos Henrique Marchiori, Instituto Luterano de Ensino Superior de Itumbiara-ILES-ULBRA, \\ Avenida Beira Rio, 1001, C.P. 23-T, CEP 75500-000, Itumbiara, Goiás, Brazil, e-mail: pesquisa.itb@ulbra.br \\ Received May 23, 2002 - Accepted August 23, 2002 - Distributed May 31, 2003
}

\begin{abstract}
This paper reports the first occurrence of the parasitoid Spalangia endius collected in pupae of Zaprionus indianus using traps with fruit bait. The experiment was carried out at the University of Lavras in Lavras, Minas Gerais, Brazil, from November to December, 2001. A total of 4 Spalangia endius specimens were obtained from 105 Zaprionus indianus pupae. The overall prevalence of parasitism was $3.8 \%$.
\end{abstract}

Key words: first occurrence, biocontrol, enemy natural, Minas Gerais, Lavras, Brazil.

\section{RESUMO}

Primeira ocorrência do parasitóide Spalangia endius (Walker) (Hymenoptera: Pteromalidae) em pupas de Zaprionus indianus Gupta (Diptera: Drosophilidae) no Brasil

Este trabalho relata a primeira ocorrência do parasitóide Spalangia endius em pupas de Zaprionus indianus obtidas por meio de armadilhas contendo isca frutas. $\mathrm{O}$ experimento foi realizado na Universidade de Lavras, Minas Gerais, Brasil, no período de novembro a dezembro de 2001. Foram coletados um total de 4 espécimes de Spalangia endius em 105 pupas de Zaprionus indianus. A prevalência total de parasitismo foi de $3,8 \%$.

Palavras-chave: primeira ocorrência, controle biológico, inimigo natural, Minas Gerais, Lavras, Brasil.

The genus Zaprionus presently numbers 56 species, and the Zaprionus indianus Gupta (Diptera: Drosophilidae) seems to be the only species spreading globally, mainly due to the international fruit trade. This Drosophilidae probably originated in Africa, where it has been found in fruits of 74 plant species (Lachaise \& Tsacas, 1983).

The first recorded occurrence of this fly in the Americas makes some references to samples observed in persimmons in Santa Isabel, São Paulo. The poliphagy and relatively short lifetime of this
Drosophilidae in an extremely hot environment have contributed to its dispersion throughout Brazil (Vilela et al., 1999). As a sample consequence, a 50\% loss in fig production was recorded in the State of São Paulo (Vilela et al., 1999, 2001).

The Pteromalidae is distributed virtually worldwide and it is one of the largest families of Chalcidoidea, containing over 3000 recognized species belonged to nearly 600 genera. The Pteromalidae hosts are diversified members of many other Insecta orders such as Hemiptera, Neuroptera, 
Coleoptera, Lepidoptera, Diptera, Siphonaptera, Hymenoptera, Dermaptera, and Homoptera. They attack eggs, larvae, pupae, and, more rarely, adults. It seems that the main contribution of pteromalids is their control over muscoid flies, especially the housefly and the stable fly (Hanson \& Gauld, 1995).

Spalangia endius (Walker) (Hymenoptera: Pteromalidae) is considered a solitary parasitoid containing a great number of Diptera in the families Anthomyiidae, Calliphoridae, Muscidae, Sarcophagidae, and Tephritidae (Hanson \& Gauld, 1995). This article reports the occurrence of the parasitoid Spalangia endius parasitizing Zaprionus indianus.

The study was conducted at the University of Lavras, in Lavras, the State of Minas Gerais $\left(21^{\circ} 14^{\prime}\right.$ 43"'S; 4459'59' W), from November to December, 2001. Flies were attracted to traps made of dull black tin cans, measuring $19 \mathrm{~cm}$ in height and $9 \mathrm{~cm}$ in diameter, with two venetian-blind type openings in the lower third to allow insect entry. On the upper part of the cans open-ended nylon funnels with their bases turned down were attached. These traps were then wrapped with plastic bags, which after removal would allow the capture of flies and parasitoids. Fruit deposited on the soil was used as bait inside the cans. Five of these traps were suspended on Eucalyptus sp. trees at $1 \mathrm{~m}$ above the soil level, 2 $\mathrm{m}$ apart from each other, and $50 \mathrm{~m}$ away from a domestic garbage deposit. The specimens collected were taken to the laboratory, sacrificed with ethyl ether, and preserved in $70 \%$ ethanol for further identification. After insect retrieval, trap contents were placed in plastic containers containing a layer of sand as substrate for the larvae population. After 15 days in the field, the sand of these containers was sifted for extraction of pupae from a therefore natural environment. These pupae were than individually transferred to gelatin capsules (number 00) to obtain flies and/or parasitoids.
The prevalence rate of parasitism was calculated by the formula: $\mathrm{P}=$ (parasite pupae/total of pupae) x 100 (Margolis et al., 1982; Bush et al., 1997). Drosophilidae identification was done by Dr. Carlos Ribeiro Vilela, from the Universidade de São Paulo, SP.

Between November and December, 2001, 4 specimens of S. endius were obtained from 105 pupae of $Z$. indianus, representing $3.8 \%$ of parasitism. The use of chemical substances to control this fly and benefit fruit exportation may result in high production costs, while causing environmental and human health damage. Thus, the search for effective natural enemies may result in an alternative capable of providing the basis for a long-term control program.

In conclusion, this is the first report of $S$. endius parasitizing pupae of $Z$. indianus in Brazil.

\section{REFERENCES}

BUSH, A. O., LAFFERTY, K. D., LOTZ, J. M. \& SHOSTAK, A. W., 1997, Parasitology meets ecology on its own terms: Margolis et al. Revisited. J. Parasitolo., 83: 575-583.

HANSON, P. E. \& GAULD, I. D., 1995, The Hymenoptera of Costa Rica. Oxford Univ. Press, Oxford, 893p.

LACHAISE, D. \& TSACAS, L., 1983, Breeding- sites in tropical african drosophilids. In: M. Asburner, H. L. Carson \& J. $\mathrm{N}$. Thompson Jr. (eds.), The genetics and biology of Drosophila. Academic Press. Inc., London.

MARGOLIS, L., ESCH, G. W., HOLMES, J. C., KURIS, A. M. $\&$ SCHAD, G. A., 1982, The use of ecological terms in parasitology (report of an ad hoc committee of the American Society of Parasitologists). J. Parasitol., 68: 131-133.

VILELA, C. R., TEIXEIRA, E. P. \& STEIN, C. P., 1999, Nova praga nos figos: Zaprionus indianus Gupta, 1970. Informa. Soc. Entomol. Bras., 4: 1-5.

VILELA, C. R., TEIXEIRA, E. P. \& STEIN, C. P., 2001, Moscaafricana-do-figo, Zaprionus indianus (Diptera: Drosophilidae), pp. 48-52. In: E. F. Vilela, R. A. Zucchi \& F. Cantor (orgs.), Pragas introduzidas. 1 vol. Holos, Ribeirão Preto, 173p. 